\title{
PENGARUH KINERJA KEPALA SEKOLAH TERHADAP KEBERHASILAN MANAJEMEN BERBASIS SEKOLAH MELALUI PARTISIPASI MASYARAKAT DI SMP
}

\author{
Novi Hardini Putri, Udik Budi Wibowo \\ Prodi Manajemen Pendidikan PPs UNY, FIP Universitas Negeri Yogyakarta \\ novihardiniputri@gmail.com, udik_bw@uny.ac.id
}

\begin{abstract}
Abstrak
Penelitian ini bertujuan untuk mengukur pengaruh kinerja kepala sekolah terhadap keberhasilan manajemen berbasis sekolah melalui partisipasi masyarakat di SMP Negeri seKabupaten Karimun, Kepulauan Riau. Penelitian ini menggunakan pendekatan kuantitatif dengan jenis penelitian korelasional. Penelitian dilakukan terhadap populasi dengan jumlah 39 kepala SMP Negeri se-Kabupaten Karimun, Kepulauan Riau. Pengumpulan data menggunakan instrumen angket yang telah diuji validitasnya dengan korelasi product moment dan uji reliabilitas dengan menggunakan alpha-cronbach. Adapun analisis datanya dilakukan secara deskriptif dan analisis jalur dengan taraf signifikansi 0,05. Hasil analisis data secara deskriptif ditemukan bahwa kinerja kepala sekolah, partisipasi masyarakat dan keberhasilan MBS termasuk dalam kategori sedang yakni: kinerja kepala sekolah $=46,2 \%$, partisipasi masyarakat $=64,1 \%$ dan keberhasilan MBS $=41 \%$. Sedangkan dari analisis jalur menunjukkan bahwa terdapat pengaruh yang positif dan signifikan terhadap keberhasilan MBS di SMP Negeri Kabupaten Karimun. Selanjutnya ditemukan pengaruh tidak langsung dari kinerja kepala sekolah terhadap keberhasilan MBS melalui partisipasi masyarakat = $57,3 \%$.
\end{abstract}

Kata kunci: kinerja kepala sekolah, partisispasi masyarakat, keberhasilan manajemen berbasis sekolah

\section{THE INFLUENCE OF THE PRINCIPALS' PERFORMANCES ON THE SUCCESS OF SCHOOL-BASED MANAGEMENT THROUGH COMMUNITY PERFORMANCE AT JUNIOR SECONDARY SCHOOLS}

\author{
Novi Hardini Putri, Udik Budi Wibowo \\ Prodi Manajemen Pendidikan PPs UNY, FIP Universitas Negeri Yogyakarta \\ novihardiniputri@gmail.com, udik_bw@uny.ac.id
}

\begin{abstract}
This study aims to find out the influence of the principals' performances on the success of school-based management through community participation at Public Junior Secondary Schools in Karimun Regency, Kepulauan Riau. This study used a quantitative approach through a correlational research design. 39 principals from all Public Junior Secondary Schools in Karimun Regency were involved as population. The data were collected through questionnaires. The validity of the instrument was analyzed through product moment and the reliability through alpha-Cronbach. Then, the data were analyzed descriptively by using path analysis with the significance level of 0.05 . The finding showed that the performances of the principals' performances, and community participation on the success of MBS were included into sufficient category. They were seen from the principals' performances = $46.2 \%$, community participation $=64.1 \%$, and the success of $M B S=41 \%$. Meanwhile, from path analysis, there was a positive influence and significance on the success of MBS at Public Junior Secondary Schools in Karimun Regency. In addition, there was an indirect influence of the principals' performances on the success of MBS through community participation $=57.3 \%$.
\end{abstract}

Keywords: principals' performances, community participation, the success of school-based management 


\section{Pendahuluan}

Peningkatan mutu pendidikan merupakan peran pembangunan di bidang pendidikan Nasional. Era reformasi telah membawa perubahan-perubahan mendasar salah satunya bidang pendidikan. Perubahan mendasar yang digulirkan adalah manajemen negara, yaitu dari manajemen sentralistik ke manajemen berbasis daerah. Undang-undang tentang pemerintah daerah Nomor 23 tahun 2014 pasal 1 ayat 8 menyebutkan "Desentralisasi adalah penyerahan urusan pemerintah oleh pemerintah daerah pusat kepada pemerintah daerah otonom berdasarkan asas otonomi" (Presiden Republik Indonesia, 2014).

Penyelenggaraan pendidikan di sekolah sejak diberlakukan desentralisasi pendidikan ikut mengalami perubahan. Seperti yang dialami oleh sekolah di Kabupaten Karimun. Sekolah diberi kebebasan untuk meningkatkan mutu pendidikan masingmasing. Karena mutu pendidikan sangat bergantung pada bagaimana proses pendidikan di sekolah-sekolah, maka pihak sekolah sudah seharusnya paling mengetahui masalah yang ada di sekolah serta bagaimana solusi yang terbaik agar desentralisasi pendidikan berjalan dengan baik. Desentralisasi pendidikan di tingkat sekolah dinyatakan melalui konsep Manajemen Berbasis Sekolah (MBS).

Kewenangan yang dimiliki oleh sekolah diharapkan dapat menjadikan sekolah leluasa dalam mengambil kebijakan guna meningkatkan mutu sekolahnya. Sekolah diharapkan dapat mengakomodir kompetensi siswa-siswanya sehingga prestasi belajar siswa semakin baik. Sekolah di Kabupaten Karimun yang telah menerapkan MBS belum bisa melakukan upaya yang optimal untuk meningkatkan prestasi belajar siswa-siswanya.
Kepemimpinan merupakan suatu hal yang sangat penting dalam implementasi Manajemen Berbasis Sekolah. Namun, berdasarkan hasil wawancara pada studi pendahuluan dengan guru SMP di beberapa sekolah Kabupaten Karimun pada tanggal 6 Juli 2015 menyatakan bahwa sebagian kepala sekolah di Kabupaten Karimun masih kurang paham tentang Manajemen Berbasis Sekolah (MBS), maka dari itu Dinas Pendidikan Kabupaten Karimun mengadakan seminar untuk kepala sekolah tentang Manajemen Peningkatan Mutu Berbasis Sekolah (MPMBS).

Selain kinerja kepala sekolah, partisipasi masyarakat (khususnya orang tua siswa) sangat besar artinya bagi kemajuan pendidikan, begitu juga dalam hal peningkatan MBS. Orang tua dan masyarakat serta elemen pemangku kepentingan (stakeholder) merupakan masukan lingkungan yang ikut berpengaruh terhadap kinerja sekolah sebagai suatu sistem. Pemberian otonomi di sekolah agar dapat mengakomodasikan seluruh keinginan sekaligus memberdayakan berbagai komponen masyarakat secara efektif, guna mendukung kemajuan dan sistem yang ada di sekolah. Oleh karena itu Manajemen Berbasis Sekolah (MBS) tampil sebagai model alternatif paradigma baru dalam pendidikan.

Sekolah di Kabupaten Karimun khususnya SMP juga menerapkan MBS karena salah satu misi Dinas Pendidikan Kabupaten Karimun adalah mengembangkan manajemen sekolah melalui konsep MPMBS (Manajemen Peningkatan Mutu Berbasis Sekolah). Dengan adanya MBS diharapkan mutu pendidikan di Kabupaten Karimun bisa meningkat, salah satunya dengan meningkatnya peringkat kelulusan se-Kepulauan Riau.

Tabel 1. Jumlah Sekolah di Kabupaten Karimun

\begin{tabular}{llcccccccccc}
\hline Status Sekolah & \multicolumn{10}{c}{ Jenis/Jenjang Sekolah } & Jumlah \\
\hline Sekolah & TK & RA & SD & MI & SMP & MTS & SMA & MA & SMK & SLB & \\
\hline Negeri & 13 & - & 121 & 3 & 39 & 1 & 14 & - & 4 & 1 & 196 \\
Swasta & 48 & 9 & 13 & 9 & 8 & 9 & 3 & 5 & 4 & 2 & 110 \\
$\quad$ Total & 61 & 9 & 134 & 12 & 47 & 10 & 17 & 5 & 8 & 3 & 306 \\
\hline
\end{tabular}


Kabupaten Karimun merupakan salah satu kabupaten yang berada di Provinsi Kepulauan Riau. Kabupaten Karimun memiliki 306 sekolah yang terdiri dari sekolah negeri dan sekolah swasta.

Kepala sekolah di Kabupaten Karimun cenderung kurang mempunyai kekuatan untuk melakukan inovasi dan kreasi pendidikan sesuai dengan situasi yang berkembang dalam masyarakat. Sebagian kepala sekolah juga kurang memahami tentang MBS. Belum maksimalnya kinerja gu$\mathrm{ru}$, hal ini dapat dilihat dari beberapa guru yang terlihat belum menguasai bahan pengajaran, adanya guru yang mengajarkan bidang studi yang bukan spesialisasinya dan adanya guru datang terlambat ke sekolah. Hal ini menandakan masih adanya guru yang belum memiliki rasa tanggung jawab yang besar terhadap profesinya. Tidak ada kerja sama dan komunikasi kemitraan yang baik antara sekolah, orang tua, dan masyarakat. Kurangnya transparansi dari pihak sekolah kepada orang tua/stakeholder. Kurangnya standar sarana dan prasarana yang mendukung dalam rangka peningkatan kinerja mengajar guru serta proses pembelajaran secara efektif dan efisien. Berdasarkan latar belakang di atas, maka perlu dilakukan penelitian tentang Pengaruh Kinerja Kepala Sekolah terhadap keberhasilan MBS melalui Partisipasi Masyarakat di SMP Kabupaten Karimun Kepulauan Riau.

\section{Manajemen Berbasis Sekolah}

Manajemen Berbasis Sekolah (MBS) terjemahan dari "School Based Management (SBM)" merupakan suatu konsep yang menawarkan otonomi pada sekolah untuk menentukan kebijakan sekolah dalam rangka meningkatkan mutu, efisiensi dan pemerataan pendidikan agar dapat mengakomodasi keinginan masyarakat setempat serta menjalin kerja sama yang erat antara sekolah, masyarakat dan pemerintah (Mulyasa, 2014, p. 11). Sedangkan menurut Katuuk (2014, p. 102) manajemen berbasis sekolah adalah upaya reformasi manajemen pendidikan. Ide dasar dari pelaksanaan program MBS di sekolah adalah untuk meningkatkan kinerja berbagai lembaga pendidikan sehingga dapat meningkatkan kualitas pendidikan dan daya saing dengan memberikan kewenangan dan otonomi ke sekolahsekolah.

Manajemen berbasis sekolah dilakukan sebagai jalan pintas untuk manajemen lebih efisien dan peningkatan kualitas pendidikan. Sekolah dipaksa membuat perubahan untuk memastikan bahwa penurunan sumber daya pendidikan secara keseluruhan tidak lebih rendah. Ini menempatkan tanggung jawab besar di pundak kepala sekolah dan badan dari sekolah untuk menggunakan uang secara efektif untuk memastikan bahwa pendidikan tetap terjangkau. Manajemen berbasis sekolah dijalankan agar sekolah membuat perubahan, salah satunya tentang biaya sekolah. Sehingga, anak-anak yang tidak memiliki biaya juga dapat mengenyam pendidikan dengan layak. Menurut Nurkolis (2006, p. 23) tujuan MBS adalah meningkatkan kualitas pendidikan secara umum, baik itu menyangkut kualitas pembelajaran, kurikulum, sumber daya manusia baik guru maupun tenaga kependidikan lainnya dan kualitas pelayanan pendidikan.

Pelaksanaan MBS disesuaikan dengan potensi dan kebutuhan masing-masing sekolah. MBS dapat berjalan dengan efektif apabila didukung oleh SDM yang profesional untuk mengoperasikan sekolah, dana yang cukup, sarana prasarana yang memadai untuk proses pembelajaran, serta dukungan dari masyarakat. Dalam pelaksanaan MBS menuntut partisipasi lebih besar dari warga sekolah bersama stakeholder dalam setiap pengambilan keputusan kebijakan pendidikan di sekolah. Dengan demikian semua ikut bertanggung jawab atas nasib sekolah. MBS harus disosialisasikan secara matang agar berbagai pihak yang terkait mengetahui dan memahami arti pentingnya implementasi MBS. Kompleknya permasalahan yang dihadapi sekolahsekolah di Indonesia menjadi kendala dalam pelaksanaan otonomi sekolah. Oleh karena itu dalam implementasi MBS perlu dilakukan melalui beberapa tahap. Ada tiga tahap pelaksanaan MBS yaitu: jangka pendek (tahun pertama sampai dengan tahun 
ketiga), jangka menengah (tahun keempat sampai dengan tahun keenam) dan jangka panjang (setelah tahun keenam).

Menurut Nurkolis (2006, p. 271) keberhasilan implementasi MBS di Indonesia dapat dinilai setidaknya dari sembilan kriteria, yaitu: (1) MBS dianggap berhasil apabila jumlah siswa yang mendapat layanan pendidikan semakin meningkat; (2) MBS dianggap berhasil apabila kualitas layanan pendidikan menjadi lebih baik. Karena layanan pendidikan yang berkualitas mengakibatkan prestasi akademik dan prestasi non-akademik siswa juga meningkat; (3) tingkat tinggal kelas menurun dan produktivitas sekolah semakin baik dalam arti rasio antara jumlah siswa yang mendaftar dengan jumlah siswa yang lulus menjadi lebih besar; (4) relevansi penyelenggaraan pendidikan semakin baik karena programprogram sekolah dibuat bersama-sama dengan warga masyarakat dan tokoh masyarakat; (5) terjadinya keadilan dalam penyelenggaraan pendidikan karena penentuan biaya pendidikan tidak dilakukan secara pukul rata, tetapi didasarkan pada kemampuan ekonomi masing-masing keluarga; (6) semakin meningkatnya keterlibatan orang tua dan masyarakat dalam pengambilan keputusan di sekolah, baik yang menyangkut keputusan instruksional maupun organisasional; (7) semakin baiknya iklim dan budaya kerja di sekolah; (8) kesejahteraan guru dan pegawai sekolah membaik antara lain karena sumbangan pemikiran, tenaga dan dukungan dana dari masyarakat lua; dan (9) akan terjadinya demokratisasi dalam penyelenggaraan pendidikan.

Faktor-faktor keberhasilan manajemen berbasis sekolah menurut Fullan \& Watson (1999, p. 25) adalah: (1) metode pengajaran dan pembelajaran model baru; (2) Kepala sekolah yang aktif; (3) mengembangkan hubungan antara guru di dalam dan luar sekolah; (4) partisipasi orang tua dan masyarakat yang aktif; (5) membangun struktur eksternal untuk melatih dan mendukung kepala sekolah, guru dan lain-lain; dan (6) akuntabilitas dan transparansi.

MBS, yang ditandai dengan otonomi sekolah dan pelibatan masyarakat merupa- kan respon pemerintah terhadap gejalagejala yang muncul di masyarakat, bertujuan untuk meningkatkan efisiensi, mutu, dan pemerataan pendidikan. Peningkatan efisiensi, antara lain diperoleh melalui keleluasaan mengelola sumber daya partisipasi masyarakat dan penyederhanaan birokrasi. Sementara peningkatan mutu dapat diperoleh, antara lain, melalui partisipasi orang tua terhadap sekolah, fleksibilitas pengelolaan sekolah dan kelas, peningkatan profesionalisme guru dan kepala sekolah. Peningkatan pemerataan antara lain diperoleh melalui peningkatan partisipasi masyarakat yang memungkinkan pemerintah lebih berkonsentrasi pada kelompok tertentu.,

Pada prinsipnya MBS bertujuan untuk memberdayakan sekolah dalam menetapkan berbagai kebijakan internal di sekolah yang mengarah pada peningkatan mutu pendidikan dan kinerja sekolah secara keseluruhan. Kepala sekolah memiliki kekuasaan penuh untuk menjalankan sekolahnya. Selain itu, MBS merupakan salah satu upaya pemerintah untuk mencapai keunggulan masyarakat bangsa dalam penguasaan ilmu dan teknologi. Untuk itu partisipasi masyarakat dalam MBS sangat dibutuhkan karena masyarakat merupakan salah satu stakeholder dalam dunia pendidikan. Oleh karena itu penelitian ini mengambil variabel kinerja kepala sekolah dan partisipasi masyarakat.

\section{Kinerja Kepala Sekolah}

Pendidikan di sekolah tidak lepas dari tanggung jawab kepala sekolah. Kepala sekolah memainkan peran sebagai pemimpin dan manajer. Kepala sekolah memegang posisi yang sangat penting dalam seluruh sistem pendidikan. Kepemimpinan yang efektif menjadi aset dari setiap organisasi yang ingin mencapai produktivitas termasuk sekolah (Boateng, 2012, p. 128).

Ada lima bidang kinerja kepala sekolah yang harus dimiliki kepala sekolah dalam meningkatkan prestasi siswa dan staf yaitu: pemecahan masalah secara kolaboratif dan komunikasi terbuka; mengumpulkan, menganalisis, dan menggunakan data untuk mengidentifikasi kebutuhan sekolah; menggunakan data untuk mengidentifikasi 
dan merencanakan perubahan yang dibutuhkan dalam program pembelajaran; melaksanakan dan memantau rencana perbaikan sekolah; menggunakan sistem berpikir dan fokus yang jelas untuk mencapai tujuan prestasi siswa.

Selain itu, kepala sekolah adalah orang yang paling bertanggung jawab dalam sekolah baik yang terkait dengan manajemen, administrasi atau pelaksanaan semua kebijakan dan praktik pendidikan". Kepala sekolah sebagai pemimpin di sekolah merupakan tenaga fungsional guru yang diberi tugas untuk memimpin suatu sekolah, tempat diselenggarakannya proses belajar mengajar atau tempat terjadinya interaksi antara guru yang memberi pelajaran dan murid yang menerima pelajaran.

Menurut Usman (Karwati \& Priansa, 2013, p. 37), kepala sekolah sebagai manager dituntut mengorganisir seluruh sumber daya sekolah menggunakan prinsip teamwork, yang mengandung pengertian adanya rasa kebersamaan (together), pandai merasakan (empathy), saling membantu (assist), saling penuh kedewasaan (maturity), saling mematuhi (willingness), saling teratur (organization), saling menghormati (respect) dan saling berbaik hati (kindness).

Keberhasilan pendidikan di sekolah sangat ditentukan oleh keberhasilan kepala sekolah dalam mengelola tenaga kependidikan yang tersedia di sekolah. Kepala sekolah merupakan salah satu komponen pendidikan yang berpengaruh dalam meningkatkan kinerja guru. Kepala sekolah bertanggung jawab atas penyelenggaraan kegiatan pendidikan, administrasi sekolah, pembinaan tenaga kependidikan lainnya dan pendayagunaan serta pemeliharaan sarana dan prasarana (Mulyasa, 2014, p. 25). MBS membutuhkan fleksibilitas yang lebih besar oleh kepala sekolah dalam mengelola sumber daya dan mendorong partisipasi warga sekolah dan masyarakat untuk meningkatkan mutu pendidikan.

Partisipasi Masyarakat

Partisipasi dalam bahasa inggris yaitu participation berarti pengambilan bagian, pengikutsertaan. Menurut Davis (1987, p.
179) partisipasi bukan teori yang tidak berguna yang dikembangkan oleh seseorang mencari ide baru. Manfaat besar dari partisipasi adalah mengembalikan hak-hak asasi anggota untuk memberikan kontribusi kepada kelompok di mana mereka bekerja. Orang tua sangat memainkan peranan penting dalam pendidikan anak.

Kepala sekolah sebagai penanggung jawab tertinggi di sekolah haruslah tampil paling depan dalam memajukan kerjasama antara sekolah dengan masyarakat. Karena kepala sekolah selain sebagai penanggung jawab tertinggi di sekolah juga merupakan orang yang paling berkepentingan dan tahu akan masalah-masalah yang dihadapi oleh sekolah. Oleh sebab itulah kepala sekolah menjadi motor penggerak kemajuan kerja sama sekolah dengan masyarakat. Program sekolah tidak dapat berjalan dengan lancar apabila tidak mendapat partisipasi dari masyarakat. Oleh karena itu kepala sekolah/pemimpin di sekolah perlu terus membina hubungan yang baik antara sekolah dan masyarakat. Sekolah juga perlu memberikan informasi kepada masyarakat tentang program-program yang sedang dan akan dijalankan, agar masyarakat mengetahui dan memahami programprogram apa saja yang sedang berjalan dan akan dijalankan oleh sekolah.

Manajemen berbasis sekolah dan desentralisasi pendidikan di Amerika Latin telah muncul sebagai alat penting dari kebijakan pendidikan. Manfaat yang diduga desain manajemen berbasis sekolah bergantung dari sebagian besar orangtua siswa. Partisipasi orang tua siswa dalam programprogram yang pemerintah rancang untuk pengambilan keputusan yang berhubungan dengan sekolah (McNamara, 2010, p. 1). Partisipasi orang tua/masyarakat dalam penyelenggaraan pendidikan sekolah sangatlah penting karena dapat mempengaruhi keberhasilan penyelenggaraan proses pendidikan. Faktor-faktor yang mempengaruhi partisipasi masyarakat harusnya dapat diminimalisir agar partisipasi masyarakat dapat berjalan dengan lancar dan dapat meningkatkan kualitas penyeleggaraan pendidikan. 
Tingkat partisipasi masyarakat dalam proses pendidikan di sekolah memberikan pengaruh yang positif bagi kemajuan sekolah, kualitas pelayanan pembelajaran di sekolah yang pada akhirnya akan berpengaruh terhadap kemajuan dan prestasi belajar anak-anak di sekolah. Anak-anak berhak mendapatkan pendidikan yang layak. Oleh karena itu, untuk lebih memaksimalkan tujuan pendidikan yang ingin dicapai, diperlukan adanya hubungan antara sekolah dengan masyarakat yang baik melalui partisipasi masyarakat. Sehingga tujuan pendidikan yang ingin dicapai bisa dimaksimalkan.

Menurut Slamat (Rodliyah, 2013, p. 56), faktor-faktor yang mempengaruhi partisipasi masyarakat adalah sebagai berikut. Pertama adalaha jenis kelamin. Partisipasi yang diberikan oleh pria akan berbeda dengan partisipasi yang diberikan wanita. Hal ini disebabkan adanya sistem pelapisan sosial yang terbentuk dalam masyarakat yang membedakan kedudukan dan derajat antara pria dan wanita, sehingga menimbulkan perbedaan-perbedaan hak dan kewajiban. Kedua adalah usia. Terdapat perbedaan kedudukan dan derajat atas dasar senioritas dalam masyarakat, sehingga memunculkan golongan tua dan golongan muda yang berbeda-beda dalam hal tertentu. Usia produktif juga sangat mempengaruhi pola berfikir masyarakat dalam ikut serta meningkatkan kualitas pendidikan. Ketiga adalah tingkat pendidikan. Tingkat pendidikan mempengaruhi masyarakat dalam berpartisipasi. Karena dengan latar belakang pendidikan yang diperoleh, seseorang lebih mudah berkomunikasi dengan orang luar dan cepat tanggap terhadap inovasi pendidikan serta memiliki rasa tanggung jawab yang tinggi terhadap kualitas pendidikan. Keempat adalah tingkat penghasilan. Besarnya tingkat penghasilan akan memberi peluang lebih besar bagi masyarakat atau orang tua untuk berperan serta. Tingkat penghasilan mempengaruhi kemampuan finansial masyarakat untuk berpartisipasi dalam pendanaan sekolah dan berinvestasi untuk kemajuan sekolah. Kelima adalah mata pencaharian. Jenis pe- kerjaan seseorang akan menentukan tingkat penghasilan dan mempengaruhi waktu luang seseorang yang digunakan dalam berpartisipasi. Selain itu juga mempengaruhi kesanggupan masyarakat khususnya orang tua dalam menanggung biaya pendidikan anak.

Untuk menjalankan manajemen berbasis sekolah, maka sekolah membutuhkan membutuhkan partisipasi dari masyarakat. Untuk itu dibentuklah perwakilan dari masyarakat yang disebut komite sekolah. Peran serta komite sekolah menurut Nurkolis (2006, p. 127) antara lain: (1) Penggerak, dengan membentuk badan kerja sama pendidikan menghimpun kekuatan dari masyarakat agar semakin peduli terhadap pendidikan, dengan salah satu caranya membentuk Lembaga Swadaya Masyarakat (LSM); (2) Informan dan penghubung, yaitu menginformasikan harapan dan kepentingan masyarakat dengan sekolah dan menginformasikan kondisi sekolah, baik kekurangan maupun kelebihan sekolah kepada masyarakat sehingga masyarakat tahu persis keadaan sekolah; (3) Koordinator, yaitu mengkoordinasikan kepentingan sekolah dengan kebutuhan di lingkungan masyarakat, agar siswa siswi diberi kesempatan untuk bekerja secara mandiri di masyarakat; dan (4) Pengusul, yaitu mengusulkan kepada pemerintah daerah agar dilakukan pendanaan untuk pendidikan agar semakin maju dan bermutu dengan dilaksanakannya pajak untuk pendidikan. Artinya, lembaga bisnis dan individu dikenai pajak untuk pendanaan pendidikan.

Ada beberapa contoh partisispasi masyarakat dalam pendidikan menurut Rodliyah (2013, p. 35) yaitu: (1) Mengawasi perkembangan pribadi dan proses belajar putra putrinya di rumah dan bila perlu memberi laporan dan berkonsultasi dengan pihak sekolah; (2) Menyediakan fasilitas belajar di rumah dan membimbing putraputrinya agar belajar dengan penuh motivasi dan perhatian; (3) Menyediakan perlengkapan belajar yang dibutuhkan untuk belajar di lembaga pendidikan sekolah; (4) Berusaha melunasi SPP dan bantuan pendidikan lainnya; (5) Memberikan umpan 
balik kepada sekolah tentang pendidikan, terutama yang menyangkut keadaan putraputrinya; (6) Bersedia datang ke sekolah bila di undang atau diperlukan oleh sekolah; dan (7) Ikut berdiskusi dalam memecahkan masalah.

Dengan melibatkan masyarakat dalam pengelolaan sekolah maka beban pemerintah dapat berkurang. Di samping itu, berkurangnya liku-liku birokrasi dalam prinsip desentralisasi juga mendukung efisiensi sekolah. Mengikutsertakan kepala sekolah dan guru dalam pengambilan keputusan sekolah, dapat mendorong rasa kepemilikan yang tinggi dari warga sekolah terhadap sekolahnya. Hal ini pada akhirnya mendorong mereka untuk menggunakan sumber daya yang ada secara efisien untuk mencapai hasil yang optimal.

Berdasarkan uraian yang telah disampaikan tersebut, maka penelitian ini bertujuan untuk mengukur pengaruh kinerja kepala sekolah terhadap keberhasilan manajemen berbasis sekolah melalui partisipasi masyarakat di SMP Negeri seKabupaten Karimun, Kepulauan Riau

\section{Metodelogi Penelitian}

Penelitian ini untuk mengetahui pengaruh kinerja kepala sekolah terhadap manajemen berbasis sekolah melalui partisipasi masyarakat di SMP Negeri Kabupaten Karimun, Kepulauan Riau. Sesuai dengan masalah yang akan dikaji, maka penelitian ini menggunakan pendekatan kuantitatif dengan desain non eksperimen, berarti peneliti tidak mengadakan perlakuan terhadap subjek penelitian. Jenis penelitian yang akan digunakan dalam penelitian ini adalah jenis penelitian korelasional.

Penelitian ini mengambil lokasi di Sekolah Menengah Pertama Negeri Kabupaten Karimun, Kepulauan Riau. Penelitian ini dilaksanakan pada bulan FebruariMaret 2016. Populasi adalah keseluruhan subyek penelitian. Populasi dalam penelitian ini adalah 39 kepala sekolah SMP Negeri di Kabupaten Karimun, Kepulauan Riau. Penelitian ini merupakan penelitian populasi, karena populasi penelitian masih dapat dijangkau. Penelitian populasi dilakukan agar dapat menggambarkan keseluruhan populasi.

Variabel dalam penelitian ini terdiri dari variabel bebas dan variabel terkait. Variabel bebas (independent) terdiri atas kinerja kepala sekolah $\left(\mathrm{X}_{1}\right)$, partisipasi masyarakat $\left(X_{2}\right)$, dan sebagai variabel terikat (dependent) dalam penelitian ini adalah keberhasilan MBS (Y).

Kinerja kepala sekolah adalah segala upaya yang dilakukan dan hasil yang dapat dicapai oleh kepala sekolah dalam mengimplementasikan MBS di sekolahnya untuk mewujudkan tujuan pendidikan secara efektif dan efisien. Partisipasi masyarakat adalah proses dimana warga sekolah dan masyarakat terlibat aktif, baik secara individual maupun kolektif, secara langsung maupun tidak langsung dalam pengambilan keputusan, pembuatan kebijakan, perencanaan, pelaksanaan, pengawasan/ pengevaluasian pendidikan di sekolah. Sedangkan keberhasilan manajemen berbasis sekolah adalah ketercapaian sekolah dalam menjalankan manajemen berbasis sekolah.

Hipotesis dalam penelitian ini dapat digambarkan sebagai berikut:

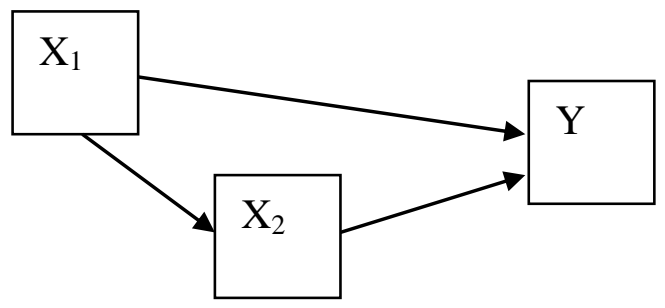

Gambar 1. Hipotesis Penelitian

Keterangan:

$\mathrm{X}_{1}$ : Kinerja Kepala Sekolah

$\mathrm{X}_{2}$ : Partisipasi Mayarakat

$Y$ : Keberhasilan MBS

Aspek-aspek yang akan diungkap melalui instrumen kuesioner ini merupakan aspek-aspek yang berkaitan dengan kinerja kepala sekolah, partisipasi masyarakat dan keberhasilan manajemen berbasis sekolah (MBS). Teknik pengumpulan data dalam penelitian ini menggunakan metode angket. Penggunaan metode angket dikare- 
nakan penelitian ini merupakan penelitian non-eksperimen untuk mengetahui apakah ada pengaruh antara kinerja kepala sekolah terhadap keberhasilan manajemen berbasis sekolah melalui partisipasi masyarakat.

Penyusunan angket dilakukan dengan menggunakan jenis rating-scale. Angket dengan skala interval dalam penelitian ini akan menyediakan jawaban dengan skala 4 dengan pilihan jawaban sangat tidak baik/tidak pernah, tidak baik/jarang, baik/sering, sangat baik/selalu. Skala interval dengan skala 4 digunakan dalam penelitian ini untuk mengukur bagaimana penilaian responden terhadap kinerja kepala sekolah terhadap manajemen berbasis sekolah melalui partisipasi masyarakat di SMP Negeri Kabupaten Karimun, Kepulauan Riau. Skala interval akan memberikan hasil lebih beragam/gradasi sehingga memungkinkan peneliti mendapatkan hasil yang lebih komprehensif.

Instrumen disusun berdasarkan kisikisi umum. Kisi-kisi instrumen meliputi instrumen kinerja kepala sekolah, partisipasi masyarakat dan keberhasilan MBS. Penyusunan item angket harus berpedoman pada kisi-kisi instrumen penelitian yang sudah dirancang. Kisi-kisi penyusunan instrumen menunjukkan kaitan antara variabel yang diteliti dengan sumber data yang akan diambil, metode yang digunakan dan instrumen yang disusun.

Pengujian validitas instrumen penelitian ini menggunakan professional judgment. Validitas empiris dilakukan dengan mengujicobakan instrumen kepada 10 kepala sekolah di Kabupaten Natuna, Kepulauan Riau yang dijadikan sampel untuk mengetahui tingkat valid/sahih tidaknya kuesioner tersebut. Apabila hasil analisis uji coba kuesioner ditemukan korelasi partwhole $\mathrm{r}_{\mathrm{pq}}$ tiap-tiap item lebih besar dari 0,3 maka dinyatakan valid. Menurut Riduwan (2014, p. 227) uji validitas ini menggunakan rumus korelasi product moment yaitu sebagai berikut:

$$
r_{x y}=\frac{N \sum X Y-\left(\sum X\right)\left(\sum Y\right)}{\sqrt{\left[N \sum X^{2}-\left(\sum X\right)^{2}\right]\left[N \sum Y^{2}-\left(\sum Y\right)^{2}\right]}}
$$

Keterangan:

$\mathrm{r}_{\mathrm{xy}}=$ Koefisien Korelasi $\mathrm{X}$ dan $\mathrm{Y}$

$\mathrm{N}=$ jumlah butir instrumen

$\sum X Y=$ jumlah dari produk $X$ dan $Y$

$\sum X=$ jumlah harga dari skor butir

$\sum Y=$ jumlah harga dari skor total

$\sum X^{2}=$ jumlah $X$ kuadrat

$\sum Y^{2}=$ jumlah $Y$ kuadrat

Uji reliabilitas dimaksudkan untuk mengetahui konsistensi alat ukur dalam penggunaannya atau dengan kata lain alat ukur tersebut mempunyai hasil konsisten apabila digunakan berkali-kali pada waktu yang berbeda. Suatu instrumen dikatakan reliabel apabila nilai $r$ hitung lebih besar dari $r$ tabel. Pengujian reliabilitas dilakukan dengan bantuan software SPSS 19.0 yang akan menghitung koefisien reliabilitas Alpha-Cronbach, dengan rumus koefisien Alpha-Cronbach menurut Sugiyono (2012, p. 365) sebagai berikut:

$$
r_{i}=\left(\frac{k}{k-1}\right)\left(1-\frac{\sum s_{i}^{2}}{s_{t}{ }^{2}}\right)
$$

keterangan:

$\mathrm{r}_{\mathrm{i}} \quad=$ reliabilitas instrumen

$\mathrm{k} \quad=$ mean kuadrat antara subyek

$\sum \mathrm{Si}^{2}=$ mean kuadrat kesalahan

$\mathrm{St}^{2} \quad=$ varians total

Penghitungan uji validitas instrumen menggunakan rumus korelasi product moment dengan bantuan SPSS 19.0. Hasil uji validitas instrumen untuk variabel kinerja kepala sekolah menunjukkan bahwa dari 36 butir soal terdapat 5 butir soal yang gugur dan dinyatakan tidak valid karena harga $r_{\text {hitung }}$ lebih kecil dari $r_{\text {tabel }}(0,3)$ untuk $\mathrm{N}=10$, sehingga masih terdapat 31 butir soal yang valid. Hasil uji validitas instrumen variabel partisipasi masyarakat menunjukkan bahwa dari 20 butir soal terdapat 3 butir yang gugur dan dinyatakan tidak valid karena harga $r_{\text {hitung }}$ lebih kecil dari $r_{\text {tabel }}(0,3)$ untuk $\mathrm{N}=10$, sehingga masih terdapat 17 soal yang valid. Sedangkan hasil uji validitas instrumen variabel keberhasilan MBS menunjukkan bahwa dari 21 butir soal terdapat 3 butir yang gugur dan dinyatakan tidak valid karena harga $r_{\text {hitung }}$ 
lebih kecil dari $r_{\text {tabel }}(0,3)$ untuk $\mathrm{N}=10$, sehingga masih terdapat 18 soal yang valid.

Penghitungan koefisien reliabilitas instrumen menggunakan rumus koefisien Alpha-Cronbach dengan bantuan program SPSS 19.0. Hasil uji reliabilitas instrumen variabel kinerja kepla sekolah sebesar 0,962, partisipasi masyarakat sebesar 0,952 dan keberhasilan MBS sebesar 0,947 sehingga instrumen dinyatakan reliabel karena koefisien korelasi lebih dari 0,600.

Analisis data deskriptif digunakan untuk memberi deskripsi mengenai data penelitian. Variabel kinerja kepala sekolah, partisipasi masyarakat dan keberhasilan manajemen berbasis sekolah dibuat kriteria berdasarkan hasil nilai rata-rata (mean). Kriteria yang dimaksud adalah tinggi, sedang dan rendah.

Regresi ganda digunakan untuk mengetahui apakah secara bersama-sama variabel bebas $\left(X_{1}, X_{2}, X_{3}\right)$ berpengaruh terhadap variabel terikat $(Y)$. Bentuk persamaan garis regresi gandanya (Sugiyono, 2012, p. 275) adalah sebagai berikut.

$$
\dot{Y}=a+b_{1} X_{1}+b_{2} X_{2}+b_{3} X_{3} \text {. }
$$

Pada dasarnya analisis jalur merupakan pengembangan dari analisis korelasi yang dibangun dari diagram jalur yang dihipotesiskan oleh peneliti.

\section{Hasil Penelitian dan Pembahasan}

Pada bagian ini dijelaskan atau dideskripsikan hasil data penelitian dari masing-masing variabel dari nilai rata-rata (mean), median, modus dan standar deviasi dengan bantuan program International Business Machine Statistical Products and Solution Services versi 19 atau dikenal dengan IBM SPSS Statistics 19. Untuk mengidentifikasi lebih lanjut mengenai variabel digunakan rerata ideal (Mi) dan Simpangan baku ideal (Sdi) dari setiap variabel. Rumus yang digunakan adalah sebagai berikut:

$\mathrm{Mi}=1 / 2($ skor tertinggi + skor terendah $)$ Sdi $=1 / 6$ (skor tertinggi - skor terendah)

Berdasarkan teknik analisis data dengan metode deskriptif, Azwar (2014, p.
149) mengemukakan bahwa skor mentah dapat dirubah kedalam nilai standar berskala dengan rincian sebagai berikut:

Rendah $=\mathrm{x}<\mathrm{Mi}-1,0 \mathrm{SDi}$

Sedang $=(\mathrm{Mi}-1,0 \mathrm{SDi}) \leq \mathrm{x}<(\mathrm{Mi}-1,0 \mathrm{SDi})$

Tinggi $=(\mathrm{Mi}+1,0 \mathrm{SDi}) \leq \mathrm{x}$

berikut:

Deskripsi data penelitian sebagai

\section{Kinerja Kepala Sekolah}

Kinerja kepala sekolah terdiri dari 31 item dan dinilai oleh 39 responden yang merupakan kepala sekolah SMP Negeri di Kabupaten Karimun Kepulauan Riau. Pada variabel kinerja kepala sekolah terdapat 4 alternatif jawaban dimana skor tertinggi adalah 4 dan skor terendah adalah 1. Dari hasil tabulasi data kinerja kepala sekolah diperoleh skor tertinggi sebesar 123 dan skor terendah sebesar 95. Hasil analisis yang telah dilakukan berupa harga mean (Mi) sebesar 111,38, median (Md) sebesar 111,00, modus (Mo) sebesar 111,00 dan standar deviasi (SD) sebesar 6,45.

Jumlah kelas interval diperoleh dengan menggunakan rumus $\mathrm{k}=1+3,3 \log 39, \mathrm{k}=$ $1+3,3(1,591)=6,251$ dan dibulatkan menjadi 6 kelas. Rentang data diperoleh dari rumus range $=$ (data terbesar - data terkecil), range $=(123-95)=28$. Sedangkan lebar kelas $\mathrm{I}=$ range $/ \mathrm{k}, \mathrm{I}=28 / 6=4,7$. kinerja kepala sekolah mayoritas berada pada interval 109,4-114,1 dengan frekuensi sebanyak 13 kepala sekolah (33,3\%), paling sedikit pada 95,0-99,7 yaitu 2 orang $(5,1 \%)$.

Kriteria kecenderungan variabel kinerja kepala sekolah diperoleh dari nilai maksimum dan minimum yang selanjutnya dicari mean ideal dan standar deviasi ideal. Berdasarkan perhitungan diperoleh Mi sebesar 131,0 dan SDi sebesar 21,7. respon terhadap kinerja kepala sekolah mayoritas termasuk dalam kategori sedang yaitu sebanyak 18 kepala sekolah $(46,2 \%)$ dan paling sedikit memberikan respon rendah sebanyak 7 kepala sekolah $(17,9 \%)$. Kategori sedang yang dimaksud bahwa sebagian kinerja kepala sekolah di SMP Negeri Kabupaten Karimun belum sesuai dengan ketentuan. Masih diperlukan peningkatan 
kinerja kepala sekolah agar kinerja kepala sekolah SMP Negeri Kabupaten Karimun menjadi lebih baik.

\section{Partisipasi Masyarakat}

Partisipasi masyarakat yang terdiri dari 17 item pernyataan. Dari hasil tabulasi data partisipasi masyarakat diperoleh skor tertinggi sebesar 61 dan skor terendah sebesar 45. Hasil analisis yang telah dilakukan berupa harga mean (Mi) sebesar 53,08, median (Md) sebesar 52,00, modus (Mo) sebesar 52,00 dan standar deviasi (SD) sebesar 3,65.

Jumlah kelas interval diperoleh dengan menggunakan rumus $\mathrm{k}=1+3,3 \log 39, \mathrm{k}=$ $1+3,3(1,591)=6,251$ dan dibulatkan menjadi 6 kelas. Rentang data diperoleh dari rumus range $=$ (data terbesar - data terkecil), range $=(61-45)=16$. Sedangkan lebar kelas $\mathrm{I}=$ range $/ \mathrm{k}, \mathrm{I}=16 / 6=2,7$. Partisipasi masyarakat mayoritas berada pada interval 50,6-53,3 dengan frekuensi sebanyak 21 kepala sekolah (53,8\%), paling sedikit pada 45,0-47,7 yaitu 1 orang.

Kriteria kecenderungan variabel partisipasi masyarakat diperoleh dari nilai maksimum dan minimum yang selanjutnya dicari mean ideal dan standar deviasi ideal. Berdasarkan perhitungan diperoleh Mi sebesar 53,0 dan SDi sebesar 2,67. Respon kepala sekolah terhadap partisipasi masyarakat mayoritas termasuk dalam kategori sedang yaitu sebanyak 25 kepala sekolah $(64,1 \%)$ dan paling sedikit memberikan respon rendah sebanyak 5 kepala sekolah (12,8\%). Respon sedang yang diperoleh dikarenakan sebagian dari orang tua/masyarakat hanya menyerahkan segala urusan peserta didik kepada sekolah, tidak ada inisiatif untuk ikut andil dalam memajukan sekolah.

Keberhasilan Manajemen Berbasis Sekolah

Keberhasilan manajemen berbasis sekolah yang terdiri dari 18 item dengan jumlah responden 39 kepala sekolah. Dari hasil tabulasi data keberhasilan manajemen berbasis sekolah diperoleh skor tertinggi sebesar 72 dan skor terendah sebesar 54 . Hasil analisis yang telah dilakukan berupa harga mean (Mi) sebesar 63,51, median (Md) sebesar 63,00, modus (Mo) sebesar 63,00 dan standar deviasi (SD) sebesar 4,75.

Jumlah kelas interval diperoleh dengan menggunakan rumus $\mathrm{k}=1+3,3 \log 39, \mathrm{k}=$ $1+3,3(1,591)=6,251$ dan dibulatkan menjadi 6 kelas. Rentang data diperoleh dari rumus range $=($ data terbesar - data terkecil), range $=(72-54)=18$. Sedangkan lebar kelas $\mathrm{I}=$ range $/ \mathrm{k}, \mathrm{I}=16 / 6=3$. Keberhasilan MBS mayoritas berada pada interval 60,2-63,2 dengan frekuensi 10 kepala sekolah (25,6\%), paling sedikit 63,3-66,3 yaitu 3 orang $(7,7 \%)$.

Kriteria kecenderungan variabel keberhasilan MBS diperoleh dari nilai maksimum dan minimum yang selanjutnya dicari mean ideal dan standar deviasi ideal. Berdasarkan perhitungan yang dapat dilihat pada lampiran diperoleh data Mi sebesar 63,0 dan SDi sebesar 3,0. respon kepala sekolah terhadap keberhasilan MBS mayoritas termasuk dalam kategori sedang yaitu sebanyak 16 kepala sekolah $(41,0 \%)$ dan paling sedikit memberikan respon rendah sebanyak 9 kepala sekolah (23,1\%). Keberhasilan manajemen berbasis sekolah masih dalam kategori sedang karena masih ada faktor-faktor yang mempengaruhi keberhasilan manajemen berbasis sekolah yang belum maksimal dilaksanakan.

Jadi dapat disimpulkan hasil analisis data secara deskriptif ditemukan bahwa kinerja kepala sekolah, partisipasi masyarakat dan keberhasilan MBS termasuk dalam kategori sedang yakni: kinerja kepala sekolah 46,2\%, partisipasi masyarakat 64,1\% dan keberhasilan MBS 41\%.

Sebelum pengujian hipotesis, dilakukan terlebih dahulu uji asumsi yang terdiri dari uji normalitas, uji linieritas, uji multikolinieritas dan uji heteroskedastisitas. Setelah semua lulus uji asumsi, maka pengujian hipotesis dapat dilanjutkan.

\section{Uji Normalitas}

Uji normalitas digunakan untuk mengetahui apakah data yang bersangkutan berdistribusi normal atau tidak. Untuk menguji normalitas menggunakan rumus Kolmogrov Smirnov dengan taraf signifikan- 
si 5\%. Distribusi data penelitian dinyatakan normal jika memiliki nilai probabilitas (sig) $>0,05$, dan dinyatakan tidak normal jika nilai probabilitasnya (sig) $<0,05$. Model regresi yang baik adalah model yang memiliki distribusi data normal. Tabel 2 adalah hasil dari uji normalitas yang

Tabel 2. Hasil Uji Normalitas

\begin{tabular}{llll}
\hline Variabel & $\begin{array}{l}\text { Kolmogorov } \\
\text { smirnov Z }\end{array}$ & $\begin{array}{l}\text { Signifi- } \\
\text { kansi }\end{array}$ & $\begin{array}{l}\text { Kete- } \\
\text { rangan }\end{array}$ \\
\hline $\begin{array}{l}\text { Kinerja kepala } \\
\text { sekolah }\end{array}$ & 0,593 & 0,874 & Normal \\
$\begin{array}{l}\text { Partisipasi } \\
\text { masyarakat }\end{array}$ & 1,125 & 0,159 & Normal \\
$\begin{array}{l}\text { Keberhasilan } \\
\text { MBS }\end{array}$ & 0,829 & 0,498 & Normal \\
\hline
\end{tabular}

Hasil uji normalitas menunjukkan bahwa nilai signifikansi semua variabel lebih besar dari 0,05 sehingga dapat disimpulkan data yang digunakan dalam model regresi berdistribusi normal.

\section{Uji Linearitas}

Tujuan uji linieritas adalah untuk mengetahui apakah variabel bebas dan variabel terikat mempunyai hubungan yang linier atau tidak. Jika nilai signifikansi pada masing-masing variabel bebas lebih besar dari pada nilai taraf signifikasi 0,05 , maka hubungan antara variabel bebas terhadap variabel terikat adalah linier. Hasil rangkuman uji linieritas disajikan pada Tabel 3.

Tabel 3. Hasil Uji Linieritas

\begin{tabular}{llll}
\hline Variabel & $\begin{array}{l}\text { F } \\
\text { hitung }\end{array}$ & $\begin{array}{l}\text { Signifi- } \\
\text { kansi }\end{array}$ & $\begin{array}{l}\text { Kete- } \\
\text { rangan }\end{array}$ \\
\hline $\begin{array}{l}\text { Kinerja kepala } \\
\text { sekolah }\end{array}$ & 1,507 & 1,191 & Linier \\
$\begin{array}{l}\text { Partisipasi } \\
\text { masyarakat }\end{array}$ & 0,669 & 0,742 & Linier \\
\hline
\end{tabular}

Hasil uji linieritas pada tabel di atas dapat diketahui bahwa variabel independen kinerja kepala sekolah dan partisipasi masyarakat memiliki nilai signifikansi yang lebih besar dari 0,05 dan F hitung lebih kecil daripada $\mathrm{F}$ tabel. Maka hal ini menunjukkan bahwa variabel yang digunakan penelitian adalah linier.

\section{Uji Multikolinearitas}

Uji multikolinearitas digunakan untuk mengetahui apakah dalam model regresi yang dipakai terdapat korelasi antarvariabel independen (bebas). Model yang baik adalah model yang variabel bebas tidak memiliki korelasi satu dengan yang lainnya. Untuk mengetahuinya dapat dilihat dari nilai tolerance lebih dari 0,10 dan nilai Variance Inflation Factor (VIF) kurang dari 10. Berdasarkan hasil uji multikolinieritas diperoleh hasil yang disajikan pada Tabel 4 .

Tabel 4. Hasil Uji Multikolinieritas

\begin{tabular}{lccl}
\hline \multicolumn{4}{c}{ Variabel dependen: Keberhasilan MBS } \\
Variabel & $\begin{array}{l}\text { Tole- } \\
\text { ransi }\end{array}$ & VIF & \multicolumn{1}{c}{ Keterangan } \\
\hline $\begin{array}{l}\text { Kinerja kepala } \\
\text { sekolah }\end{array}$ & 0,708 & 1,413 & $\begin{array}{l}\text { Tidak terdapat } \\
\text { Multikolinearitas }\end{array}$ \\
$\begin{array}{l}\text { Partisipasi } \\
\text { masyarakat }\end{array}$ & 0,794 & 1,259 & $\begin{array}{l}\text { Tidak terdapat } \\
\text { Multikolinearitas }\end{array}$ \\
\hline
\end{tabular}

Berdasarkan hasil tabel di atas menunjukkan bahwa variabel independen kinerja kepala sekolah dan partisipasi masyarakat memiliki nilai VIF kurang dari 10 dan nilai toleransinya di atas 0,1 . Dengan demikian pada model regresi yang digunakan tidak terjadi multikolinearitas. Artinya antar variabel independen yang terdapat dalam model tidak memiliki hubungan yang sempurna.

\section{Uji Heteroskedastisitas}

Uji heteroskedastisitas digunakan untuk mengetahui ada atau tidaknya penyimpangan asumsi klasik heteroskedastisitas yaitu adanya ketidaksamaan varian dari residual untuk semua pengamatan pada model regresi. Kriteria pengujian ini apabila signifikansi $<5 \%(0,05)$ maka terdapat heteroskedastisitas, sebaliknya jika signifikansi $>5 \%(0,05)$ maka tidak terdapat heteroskedastisitas dan penelitian dapat dilanjutkan. Hasil rangkuman uji heteroskedastisitas pada penelitian ini disajikan dalam Tabel 5. 
Tabel 5. Hasil Uji Heteroskedastisitas

\begin{tabular}{lcl}
\hline Variabel & Signifikansi & Kesimpulan \\
\hline $\begin{array}{l}\text { Kinerja kepala } \\
\text { sekolah }\end{array}$ & 0,774 & $\begin{array}{l}\text { Tidak terdapat } \\
\text { heteroskedastiistas }\end{array}$ \\
$\begin{array}{l}\text { Partisipasi } \\
\text { masyarakat }\end{array}$ & 0,539 & $\begin{array}{l}\text { Tidak terdapat } \\
\text { heteroskedastiistas }\end{array}$ \\
\hline
\end{tabular}

Berdasarkan tabel uji heteroskedastisitas dapat diketahui bahwa taraf signifikan $>0,05$ sehingga variansi masing-masing variabel bebas dan variabel terikat pada data penelitian adalah tidak terdapat heteroskedastisitas. Selain menggunakan uji Glesjer, dapat pula dilakukan pengujian dengan metode grafik yaitu Scatterplot.

Pengujian hipotesis dalam penelitian ini dilakukan dengan analisis regresi linier berganda. Analisis regresi berganda dilakukan bertahap untuk menganalisis model dengan dua variabel atau lebih.

Tabel 6. Hasil Uji Regresi Linier Berganda

\begin{tabular}{lcccc}
\hline \multicolumn{4}{c}{ Variabel dependen: Keberhasilan MBS } \\
\hline Variabel & $\begin{array}{c}\text { Standardized } \\
\text { coefficients } \\
\text { Beta }\end{array}$ & t hitung & Sig & Kesimpulan \\
\hline $\begin{array}{l}\text { Kinerja kepala } \\
\text { sekolah }\end{array}$ & 0,340 & 2,841 & 0,007 & Signifikan \\
$\begin{array}{l}\text { Partisipasi } \\
\text { masyarakat } \\
\text { Konstanta }=-9,333 \\
\quad \mathrm{R}^{2}=0,615\end{array}$ & 2,590 & 0,014 & Signifikan \\
\multicolumn{2}{c}{ F hitung $=21,272$} & & & \\
\hline
\end{tabular}

Berdasarkan Tabel 6 maka dapat diketahui persamaan regresi yang terbentuk adalah:

$$
Y=-9,333+0,340 X_{1}+0,292 X_{2}
$$

Keterangan:

$\mathrm{Y}=$ Keberhasilan MBS

$\mathrm{X}_{1}=$ Kinerja kepala sekolah

$\mathrm{X}_{2}=$ Partisipasi masyarakat

Adapun arti dari koefisien regresi tersebut adalah:

Koefisien regresi $\left(b_{1}\right)=0,340$

Koefisien regresi pada variabel pertama dapat diartikan apabila kinerja kepala sekolah meningkat lebih baik, maka akan terjadi kenaikan keberhasilan MBS sebesar 0,340 satuan atau $34,0 \%$, dengan asumsi variabel lain tetap. Arah positif berarti semakin tinggi kinerja kepala sekolah, maka semakin tinggi pula keberhasilan MBS.
Koefisien regresi $\left(b_{2}\right)=0,292$

Arah positif berarti semakin baik partisipasi masyarakat, maka semakin tinggi pula keberhasilan MBS. Nilai koefisien artinya apabila partisipasi masyarakat lebih baik, maka akan terjadi peningkatan keberhasilan MBS sebesar 0,292 satuan atau $29,2 \%$, dengan asumsi variabel lain tetap.

Konstanta $(b)=-9,333$

Konstanta merupakan angka tanpa adanya variabel, nilai konstanta menunjukkan -9,333. Hal ini berarti nilai keberhasilan MBS akan mengalami penurunan sebesar 9,333 satuan tanpa dipengaruhi variabel kinerja kepala sekolah dan partisipasi masyarakat. Tanpa adanya pengaruh variabel independen, semakin lama keberhasilan MBS akan semakin mengalami penurunan.

Analisis hipotesis pertama: Terdapat pengaruh yang positif dan signifikan antara kinerja kepala sekolah terhadap keberhasilan MBS. Hal ini dibuktikan dengan koefisien regresi yang memiliki arah positif dan nilai $t$ hitung pada variabel kinerja kepala sekolah sebesar 2,841 yang lebih besar dari $\mathrm{t}$ tabel $(2,841>2,021)$ dan nilai signifikansi sebesar 0,007 yang lebih kecil dari 0,05. Nilai koefisien regresi yang diperoleh sebesar 0,340 menunjukkan arah pengaruh positif, yang artinya semakin tinggi kinerja kepala sekolah maka semakin tinggi keberhasilan MBS di lingkungan sekolah SMP Negeri Kabupaten Karimun Kepulauan Riau. Hal ini sesuai dengan pendapat Mulyasa (2014, p. 57) untuk mengimplementasikan MBS secara efektif dan efisien, kepala sekolah perlu memiliki pengetahuan kepemimpinan, perencanaan dan pandangan yang luas tentang pendidikan. Wibawa kepala sekolah harus ditumbuhkembangkan dengan meningkatkan setiap kepedulian, semangat belajar, disiplin kerja, keteladanan dan hubungan manusiawi sebagai perwujudan iklim kerja yang kondusif. Kepala sekolah dituntut untuk melakukan fungsinya sebagai manajer sekolah dalam meningkatkan proses pembelajaran dan supervisi kelas, membina dan memberikan saran-saran positif kepada guru. 
Analisis hipotesis kedua: Terdapat pengaruh yang positif dan signifikan antara partisipasi masyarakat terhadap keberhasilan MBS. Hal ini ditunjukkan dengan nilai $t$ hitung sebesar 2,590 yang lebih kecil dari $\mathrm{t}$ tabel $(2,021)$ dan nilai signifikansi 0,014 yang lebih kecil dari 0,05. Nilai koefisien regresi yang diperoleh sebesar 0,292 menunjukkan arah pengaruh positif, yang artinya semakin tinggi partisipasi masyarakat maka semakin tinggi keberhasilan MBS di lingkungan sekolah SMP Negeri Kabupaten Karimun Kepulauan Riau. Hal ini sesuai dengan pernyataan Nurkolis (2006, p. 271) keberhasilan implementasi MBS di Indonesia dapat dinilai setidaknya dari sembilan kriteria, salah satunya adalah semakin meningkatnya keterlibatan orang tua dan masyarakat dalam pengambilan keputusan di sekolah, baik yang menyangkut keputusan instruksional maupun organisasional. Oleh karena itu partisipasi masyarakat sangatlah penting.

Terdapat pengaruh yang positif dan signifikan dari variabel kinerja kepala sekolah terhadap partisipasi masyarakat. Hal ini dibuktikan dari nilai Standardized Coefficients Beta sebesar 0,353, nilai uji $\mathrm{t}=$ 2,292 dengan nilai signifikansi sebesar 0,028 yang lebih kecil dari 0,05. Nilai koefisien regresi yang diperoleh sebesar 0,353 menunjukkan arah pengaruh positif, yang artinya semakin tinggi kinerja kepala sekolah maka semakin tinggi partisipasi masyarakat di SMP Kabupaten Karimun Kepulauan Riau. Hal ini sesuai dengan pendapat Rudman $(2003$, p. 9) manajemen kinerja kepala sekolah dipandang sebagai suatu pendekatan untuk memimpin dan mengendalikan kinerja masyarakat dengan sistematis dan menghubungkan persyaratan kerja, perilaku kerja dan imbalan kerja baik kebutuhan individu dan tujuan organisasi. Untuk itu kepala sekolah harus dapat mengajak masyarakat untuk ikut serta aktif dalam pengambilan keputusan di sekolah.

Analisis hipotesis keempat: Terdapat pengaruh yang positif dan signifikan antara kinerja kepala sekolah terhadap keberhasilan MBS melalui partisipasi masyarakat. Hal ini dibuktikan dengan nilai signi- fikansi 0,000 yang lebih kecil dari dari taraf kesalahan $5 \%(0,05)$. Nilai koefisien korelasi yang diperoleh sebesar 0,573 menunjukkan arah pengaruh positif.

Pengaruh kinerja kepala sekolah $\left(X_{1}\right)$ terhadap keberhasilan MBS (Y)

$$
\mathrm{X}_{1} \rightarrow \mathrm{Y}=0,340
$$

Pengaruh partisipasi masyarakat terhadap keberhasilan MBS (Y)

$$
\mathrm{X}_{2} \rightarrow \mathrm{Y}=0,292
$$

Pengaruh kinerja kepala sekolah $\left(X_{1}\right)$ terhadap partisipasi masyarakat $\left(\mathrm{X}_{2}\right)$

$$
\mathrm{X}_{1} \rightarrow \mathrm{X}_{2}=0,353
$$

Pengaruh kinerja kepala sekolah $\left(X_{1}\right)$ terhadap keberhasilan MBS (Y) melalui partisipasi masyarakat $\left(X_{2}\right)$

$$
X_{1} \rightarrow X_{2} \rightarrow Y=(0,353 \times 0,292)=0,103
$$

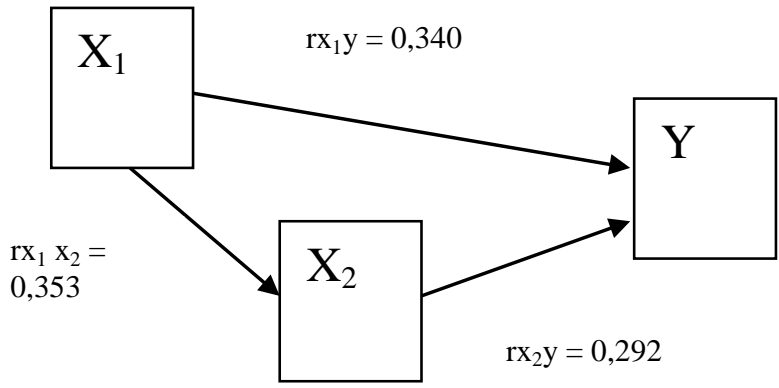

Gambar 2. Analisis Jalur

Pengaruh Kinerja Kepala Sekolah terhadap Keberhasilan MBS

Hasil hipotesis pertama dalam penelitian yang menyatakan bahwa terdapat pengaruh yang positif kinerja kepala sekolah terhadap keberhasilan MBS di SMP Negeri Kabupaten Karimun Kepulauan Riau didukung secara statistik oleh penelitian empiris. Hal ini dibuktikan dengan nilai t hitung sebesar 2,841 dan nilai signifikansi sebesar 0,007 yang lebih kecil dari 0,05 . Nilai koefisien regresi memiliki arah positif berarti semakin tinggi kinerja kepala sekolah, maka semakin tinggi pula keberhasilan MBS.

Menurut Karwati \& Priansa (2013, p. 87) peran kepala sekolah dikaitkan dengan MBS adalah segala upaya yang dilakukan dan hasil yang dapat dicapai oleh kepala sekolah dalam mengimplementasikan MBS di sekolahnya untuk mewujudkan tujuan 
pendidikan secara efektif dan efisien. MBS membutuhkan fleksibilitas yang lebih besar oleh kepala sekolah dalam mengelola sumber daya dan mendorong partisipasi warga sekolah dan masyarakat untuk meningkatkan mutu pendidikan.

Pengaruh Partisipasi Masyarakat terhadap Keberhasilan MBS

Hipotesis ketiga pada hasil uji regresi linier berganda menunjukkan nilai signifikansi pada partisipasi masyarakat sebesar 0,014 . Hasil tersebut dinilai signifikan pada tingkat signifikansi 5\%. Hasil ini menunjukkan bahwa partisipasi masyarakat secara statistik signifikan berpengaruh terhadap keberhasilan manajemen berbasis sekolah.

Menurut Pidarta (2011, p. 3) kepala sekolah sebagai penanggung jawab tertinggi di sekolah haruslah tampil paling depan dalam memajukan kerjasama antara sekolah dengan masyarakat. Karena kepala sekolah selain sebagai penanggung jawab tertinggi di sekolah juga merupakan orang yang paling berkepentingan dan tahu akan masalah-masalah yang dihadapi oleh sekolah. Oleh sebab itulah kepala sekolah menjadi motor penggerak kemajuan kerja sama sekolah dengan masyarakat.

Pengaruh Kinerja Kepala Sekolah terhadap Partisipasi Masyarakat

Nilai Standardized Coefficients Beta sebesar 0,353, nilai uji t 2,292 dengan nilai signifikansi sebesar 0,028 yang lebih kecil dari 0,05. Nilai koefisien beta menunjukkan arah pengaruh positif yang artinya semakin tinggi kinerja kepala sekolah, maka semakin tinggi partisipasi masyarakat di SMP Negeri Kabupaten Karimun Kepulauan Riau.

Partisipasi masyarakat juga akan semakin maksimal apabila hasil kinerja kepala sekolah dalam mengembangkan sekolah meningkat. Hal tersebut menjadi lebih penting sejalan dengan semakin kompleksnya tuntutan tugas kepala sekolah, yang menghendaki dukungan kinerja yang semakin efektif dan efisien. Perkembangan ilmu pengetahuan dan teknologi, serta seni dan budaya yang diterapkan dalam pen- didikan di sekolah juga cenderung bergerak semakin maju, sehingga menuntut penguasaan secara profesional (Karwati \& Priansa, 2013, p. 38).

Pengaruh Kinerja Kepala Sekolah terhadap Keberhasilan MBS melalui Partisipasi Masyarakat

Hasil penelitian empiris didapatkah nilai signifikansi sebesar 0,000. Dari data tersebut berarti pengaruh kinerja kepala sekolah terhadap keberhasilan MBS melalui partisipasi masyarakat signifikan. Dikatakan signifikan karena nilai signifikan yang didapatkan dalam uji empiris lebih kecil dari 0,05 .

Untuk mengimplementasikan MBS secara efektif dan efisien, kepala sekolah perlu memiliki pengetahuan kepemimpinan, perencanaan dan pandangan yang luas tentang pendidikan. Wibawa kepala sekolah harus ditumbuh-kembangkan dengan meningkatkan setiap kepedulian, semangat belajar, disiplin kerja, keteladanan dan hubungan manusiawi sebagai perwujudan iklim kerja yang kondusif. Kepala sekolah dituntut untuk melakukan fungsinya sebagai manajer sekolah dalam meningkatkan proses pembelajaran dan supervisi kelas, membina dan memberikan saran-saran positif kepada guru (Mulyasa, 2014, p. 57).

Partisipasi orang tua siswa dalam program-program yang pemerintah rancang untuk pengambilan keputusan yang berhubungan dengan sekolah. Untuk melibatkan masyarakat kepala sekolah harus memiliki kemampuan untuk memfasilitasi pertemuan-pertemuan atau rapat-rapat dengan anggota masyarakat (Wahyudi, 2012, p. 40). Dari penjelasan di atas maka kinerja kepala sekolah dan partisipasi masyarakat sangat berpengaruh terhadap keberhasilan manajemen berbasis sekolah.

\section{Simpulan}

Berdasarkan hipotesis penelitian maka dapat disimpulkan sebagai berikut. Pertama, kinerja kepala sekolah berpengaruh positif dan signifikan terhadap keberhasilan MBS di SMP Negeri Kabupaten Karimun Kepulauan Riau. Kedua, partisipasi 
masyarakat terhadap keberhasilan MBS di SMP Negeri Kabupaten Karimun Kepulauan Riau berpengaruh positif dan signifikan; Ketiga, kinerja kepala sekolah berpengaruh positif dan signifikan terhadap partisipasi masyarakat di SMP Negeri Kabupaten Karimun Kepulauan Riau. Keempat, kinerja kepala sekolah berpengaruh positif dan signifikan terhadap keberhasilan MBS melalui partisipasi masyarakat di SMP Negeri Kabupaten Karimun Kepulauan Riau.

Berdasarkan manfaat penelitian yang ada, peneliti memberikan beberapa saran sebagai berikut. Pertama, bagi kepala sekolah di SMP Negeri Kabupaten Karimun, Kepulauan Riau disarankan selalu menjaga komunikasi agar partisipasi masyarakat meningkat dan keberhasilan MBS yang diinginkan dapat tercapai secara maksimal.

Kedua, bagi guru disarankan untuk lebih meningkatkan kinerjanya agar nantinya kinerja tersebut dapat dipublikasikan kepada masyarakat sebagai bagian dari keberhasilan MBS. Ketiga, penelitian selanjutnya dapat mengembangkan dan menggunakan variabel lainnya yang diduga juga dapat mempengaruhi keberhasilan MBS, selain variabel yang telah diteliti untuk lebih meningkatkan keberhasilan MBS, misalnya ketersediaan sarana dan prasarana sekolah, budaya, kedisipilinan dan faktorfaktor lainnya. Keempat, bagi Dinas Pendidikan Kabupaten Karimun disarankan untuk memberikan motivasi dan evaluasi yang baik terhadap sekolah agar tercapainya keberhasilan manajemen berbasis sekolah di Kabupaten Karimun.

\section{Daftar Pustaka}

Azwar, S. (2014). Penyusunan skala psikologi. Yogyakarta: Pustaka Pelajar.

Boateng, C. (2012). Leadership styles and effectiveness of principals of vocational technical institutions in Ghana. American International Journal of Contemporary Research, 2(3), 128-134.

Davis, K. (1987). Human behavior at work: organizational behavior. New York: McGraw-Hill.

Fullan, M., \& Watson, N. (1999). School- based management:

Reconceptualizing to improve learning outcomes. In The World Bank. Univercity of Toronto.

Karwati, E., \& Priansa, D. J. (2013). Kinerja dan profesionalisme kepala sekolah. Bandung: Alfabeta.

Katuuk, D. A. (2014). Evaluation on school based management implementation in elementary school at Tomohon City, North Sulawesi. Journal of Education and Practice, 5(7). Retrieved from http://www.iiste.org/Journals/index .php/JEP/article/view/11601

McNamara, M. J. (2010). Parental participation and school-based management in nicaragua: an Ses analysis of differentiated parent participation in school councils by income, education, and community crime rates. International Journal of Education Policy and Leadership, 5, 1-13.

Mulyasa, E. (2014). Manajemen berbasis sekolah: konsep, strategi dan implementasi. Bandung: PT. Remaja Rosdakarya.

Nurkolis. (2006). Manajemen berbasis sekolah: teori, model dan aplikasi. Jakarta: Grasindo.

Pidarta, M. (2011). Manajemen pendidikan Indonesia. Jakarta: Rineka cipta.

Presiden Republik Indonesia. (2014). Undang-Undang RI Nomor 23 Tahun 2014 tentang Pemerintahan Daerah.

Riduwan. (2014). Dasar-dasar statistik. Bandung: Alfabeta.

Rodliyah. (2013). Partisipasi masyarakat dalam pengambilan keputusan dan perencanaan di sekolah. Jember: Pustaka Pelajar.

Rudman, R. (2003). Performance planning and review: making employee appraisals work. Adelaide: Allen\&Unwin.

Sugiyono. (2012). Statistika untuk penelitian. Bandung: Alfabeta.

Wahyudi. (2012). Kepemimpinan kepala sekolah dalam organisasi pembelajaran. Bandung: Alfabeta. 